\title{
Sodium bicarbonate transporter NBCe1 regulates proliferation and viability of human prostate cancer cells LNCaP and PC3
}

\author{
JUN MING LI, SOOJUNG LEE, REDA ZAFAR, EUNJUNG SHIN and INYEONG CHOI \\ Department of Physiology, Emory University School of Medicine, Atlanta, GA 30322, USA
}

Received August 31, 2020; Accepted March 29, 2021

DOI: $10.3892 /$ or.2021.8080

\begin{abstract}
Studies on cultured cancer cells or cell lines have revealed multiple acid extrusion mechanisms and their involvement in cancer cell growth and progression. In the present study, the role of the sodium bicarbonate transporters (NBCs) in prostate cancer cell proliferation and viability was examined. qPCR revealed heterogeneous expression of five $\mathrm{NBC}$ isoforms in human prostate cancer cell lines LNCaP, PC3, 22RV1, C4-2, DU145, and the prostate cell line RWPE-1. In fluorescence $\mathrm{pH}$ measurement of LNCaP cells, which predominantly express $\mathrm{NBCe} 1$, $\mathrm{Na}^{+}$and $\mathrm{HCO}_{3}{ }^{-}$-mediated acid extrusion was identified by bath ion replacement and sensitivity to the NBC inhibitor S0859. NBCel knockdown using siRNA oligonucleotides decreased the number of viable cells, and pharmacological inhibition with $\mathrm{S} 0859(50 \mu \mathrm{M})$ resulted in a similar decrease. NBCel knockdown and inhibition also increased cell death, but this effect was small and slow. In PC3 cells, which express all $\mathrm{NBC}$ isoforms, NBCe1 knockdown decreased viable cell number and increased cell death. The effects of NBCel knockdown were comparable to those by S0859, indicating that $\mathrm{NBCe} 1$ among NBCs primarily contributes to PC3 cell proliferation and viability. S0859 inhibition also decreased the formation of cell spheres in 3D cultures. Immunohistochemistry of human prostate cancer tissue microarrays revealed NBCe1 localization to the glandular epithelial cells in prostate tissue and robust expression in acinar and duct adenocarcinoma. In conclusion, our study demonstrates that NBCe1 regulates acid extrusion in prostate cancer cells and inhibiting or abolishing this transporter decreases cancer cell proliferation.
\end{abstract}

Correspondence to: Dr Inyeong Choi, Department of Physiology, Emory University School of Medicine, 605 Whitehead Research Building, 615 Michael Street, Atlanta, GA 30322, USA

E-mail: ichoi@emory.edu

Key words: sodium bicarbonate transporter, $\mathrm{pH}$ regulation, prostate cancer cell, LNCaP, PC3, knockdown, S0859

\section{Introduction}

Acid extrusion refers to an acid/base transport process by which cells move intracellular acids out of, or extracellular base equivalents into, the cytosol (1). In normal cells, acid extrusion rarely changes extracellular $\mathrm{pH}\left(\mathrm{pH}_{\mathrm{o}}\right)$ due to a large reservoir of systemic buffers. However, in tumors, acid extrusion lowers $\mathrm{pH}_{\mathrm{o}}$ in microenvironments as it counteracts excessive $\mathrm{CO}_{2}, \mathrm{H}^{+}$and lactate produced by high metabolic activity in cancer cells $(2,3)$. Furthermore, blood perfusion is limited in tumors and membrane-bound carbonic anhydrase (CA) IX contributes to extracellular $\mathrm{CO}_{2}$ hydration $(4,5)$. As a consequence, the microenvironments surrounding cancer cells are acidic while intracellular $\mathrm{pH}\left(\mathrm{pH}_{\mathrm{i}}\right)$ is normal or slightly higher than normal (6). Remarkably, cancer cells thrive in acidic environments and undergo adaptations to promote survival and proliferation, such that acidic $\mathrm{pH}_{\mathrm{o}}$ stimulates cell growth, migration and invasion (3). Abnormal $\mathrm{pH}$ gradient in cancer cells has been a focus as a potential target for anticancer therapies $(7,8)$.

$\mathrm{Na} / \mathrm{HCO}_{3}$ transporters (NBCs) are acid-extruding proteins that move $\mathrm{HCO}_{3}{ }^{-}$into cells and compensate intracellular $\mathrm{H}^{+}$(9). There are five different $\mathrm{NBCs}$ ( $\mathrm{NBCe} 1, \mathrm{NBCe} 2$, NBCn1, NDCBE, and NCBE), each of which exhibits distinct cell or tissue expression, biochemical and pharmacological properties (10-12). These transporters are of particular interest in cancer research because $\mathrm{CO}_{2}$-dependent acid production from high metabolism and excessive glycolysis corresponds to approximately half of the extracellular acids that cancer cells generate (13). Studies on cultured cancer cells in vitro or implanted in vivo have identified NBC-mediated acid extrusion mechanisms in a variety of cancer cells and their involvement in cell growth and progression $(2,14)$. Notably, NBCn1/SLC4A7 was identified as a new marker for human breast cancer (15) and its contribution to cancer progression has been recognized in MCF17 breast cancer cells $(16,17)$ and breast cancer cells from patients (18). A study using knockout mice (19) has further provided evidence that NBCn1 stimulates ErbB2-induced breast cancer development and tumor growth. Similarly, NBCe1/SLC4A4 has been revealed to regulate proliferation, migration and invasion of LS174T colon cancer cells and MDA-MB-231 breast cancer cells (20). McIntyre et al (21) screened a variety of cancer cell lines and reported the importance of NBCel and controversial SLC4A9 (AE4) for the growth of colon and breast cancer cell lines, as 
well as glioma. In addition, inhibition of NDCBE/SLC4A8 or NCBE/SLC4A10 has been revealed to decrease breast cancer cell growth (22).

As in other cancers, acidic microenvironments in prostate cancer are also considered to be an important prognostic factor (23). Acidic $\mathrm{pH}_{\mathrm{o}}$ can be used as a robust imaging biomarker for aggressive prostate cancer (24). Pharmacological inhibition or knockdown of several acid extrusion transporters, such as $\mathrm{Na} / \mathrm{H}$ exchangers NHEs $(25), \mathrm{V}$-ATPases $(26,27)$ and monocarboxylate transporters MCTs (28), prevents prostate cancer progression in vivo and in vitro. Furthermore, increasing systemic buffers by $\mathrm{NaHCO}_{3}$ has been shown to reduce a transition from intraductal carcinoma to invasive cancer in a mouse model (29). Regarding NBCs, NBCel is associated with prostate cancer $(30,31)$. NBCel is one of the gene products upregulated in a mouse model of prostate cancer induced by a deletion of the tumor suppressor gene Atbf1 (30). Increased copy numbers of the SLC4A4 gene are found in patients with prostate cancer (31). In a preliminary study by our group it was demonstrated that NBCe1 was expressed in LNCaP and PC3 prostate cancer cells and regulated acid extrusion in these cells (32). However, further studies are required.

In this study, NBCel expression levels in multiple human prostate cancer cells, NBCel-mediated $\mathrm{pH}$ recovery from intracellular acidification, and its effects on cell proliferation and death were investigated. Prostate cancer was focused on because no study has been reported on the role of this transporter in prostate cancer, despite the fact that prostate cancer is the second most frequent cancer and the fifth leading cause of cancer-related deaths among men (33). The results revealed that, among NBCs, NBCe1 played a key role in acid extrusion in prostate cancer cells and affected cell proliferation and viability. NBCe1 localization to the epithelial cells in prostatic glands and its extensive expression in acinar and duct adenocarcinoma were also demonstrated. The present results demonstrate the importance of $\mathrm{NBCel}$ for $\mathrm{pH}_{\mathrm{i}}$ regulation and growth of prostate cancer cells and leads to the possibility to develop NBCe1-mediated $\mathrm{pH}$ regulation as a potential target for anticancer treatment.

\section{Materials and methods}

Cell culture. Authenticated LNCaP cells (LNCaP-FGC) were purchased from American Type Culture Collection ATCC (cat. no. CRL-1740), and PC3, 22RV1, C4-2, DU145 and RWPE1 were provided by Dr Carlos Moreno and Dr Wei Zou at the Winship Cancer Institute of Emory University. Cells were previously authenticated by each investigator's laboratory. Cells were maintained in RPMI1640 medium (ATCC) supplemented with $10 \%$ fetal bovine serum and $1 \%$ pen/strep (Thermo Fisher Scientific, Inc.) in a $5 \% \mathrm{CO}_{2}$-equilibrated $37^{\circ} \mathrm{C}$ incubator. For hypoxic exposure, cells were incubated in a humidified atmosphere of $1 \% \mathrm{O}_{2}, 5 \% \mathrm{CO}_{2}$ at $37^{\circ} \mathrm{C}$. N-cyanosulphonamide $\mathrm{S} 0859$ (cat. no. 1019331-10-2; Millipore Sigma; Merck KGaA) was added to media in experiments that required pharmacological inhibition of NBCs. Viable cells were counted using the trypan blue exclusion assay (34). Percent of viable cells was calculated by the ratio of live cell number to total cell number (live cells + trypan blue-stained cells).
Measurements of $\mathrm{pH}_{i}$. Cells at the density of $1-2 \times 10^{5}$ were plated in a $60-\mathrm{mm}$ dish containing a poly-lysine-coated coverslip and incubated for 2 days. Cells on a coverslip were loaded with $6.5 \mu \mathrm{M}$ of 2,7-bis(2-carboxyethyl)-5(6)-carboxyfluorescein acetoxymethyl ester (BCECF-AM; cat. no. B1170; Thermo Fisher Sientific, Inc.) for $20 \mathrm{~min}$ and mounted in a closed perfusion chamber affixed to the stage of a Zeiss Axiovert inverted microscope. The dye was alternately excited with 440 and $490 \mathrm{~nm}$ lights using a Lambda LS/30 Xenon Arc lamp (Sutter Instruments), and $535 \mathrm{~nm}$ emission lights from both excitations were captured using a Nikon camera and analyzed using Nikon NIS Elements AR 3.0 imaging software (both from Nikon Corporation). The emission ratio 490/440 nm was calculated and converted to a $\mathrm{pH}$ value according to the nigericin method (35). The chamber was perfused with HEPES-buffered solution (mM: $140 \mathrm{NaCl}, 1 \mathrm{KCl}, 1.2 \mathrm{MgCl}_{2}, 1$ $\mathrm{CaCl}_{2}, 8.8$ sucrose, $\left.10 \mathrm{HEPES}, \mathrm{pH} 7.4\right)$ and then with a solution containing $5 \% \mathrm{CO}_{2}, 28 \mathrm{mM} \mathrm{HCO}_{3}{ }^{-}\left(\mathrm{NaHCO}_{3}\right.$ replaced $\mathrm{NaCl}$ ). Solutions contained $100 \mu \mathrm{M}$ of amiloride to block endogenous NHEs. S0859 at $50 \mu \mathrm{M}$ was added in experiments that required inhibition of $\mathrm{NBCs}$. For $\mathrm{Na}^{+}$-free $\mathrm{CO}_{2} / \mathrm{HCO}_{3}{ }^{-}$ solution, $\mathrm{LiCl}$ replaced $\mathrm{NaCl}$ and choline bicarbonate replaced $\mathrm{NaHCO}_{3}$. The rate of $\mathrm{pH}_{\mathrm{i}}$ recovery $(\mathrm{dpH} / \mathrm{dt}$; $\mathrm{pHi}$ change per sec $\mathrm{x} 10^{-4}$ ) was calculated by drawing a slope in the first 4 min of recovery from a $\mathrm{CO}_{2}$-induced acidification.

Reverse transcription-quantitative $(R T-q) P C R$. Total RNAs from the aforementioned cells were isolated using RNeasy Mini kit (Qiagen, Inc.) and transcribed using SuperScript III First-Strand Synthesis System (Thermo Fisher Scientific, Inc.) according to the manufacturer's protocol. qPCR was performed using Applied Biosystems SYBR Green PCR Master Mix (Applied Biosystems; Thermo Fisher Scientific, Inc.) with the following primers purchased from OriGene Technologies, Inc.: SLC4A4 (cat. no. HP232301), SLC4A5 (cat. no. HP214119), SLC4A7 (cat. no. HP207103), SLC4A8 (cat. no. HP227521), SLC4A10 (cat. no. HP214322), $\beta$-actin ACTB (cat. no. HP204660), and 18S RNA (cat. no. HP220445). The sequences are listed Table SI. Reactions were performed using an ABI Prism 7900HT Sequence Detection System (Applied Biosystems; Thermo Fisher Scientific, Inc.). Amplification was achieved at $50^{\circ} \mathrm{C}$ for $2 \mathrm{~min}$ and $95^{\circ} \mathrm{C}$ for $10 \mathrm{~min}$ for an initial denaturation, and then 40 cycles at $95^{\circ} \mathrm{C}$ for $15 \mathrm{sec}$ and $60^{\circ} \mathrm{C}$ for $1 \mathrm{~min}$. The quantification cycle $(\mathrm{Cq})$ was determined using the software SDS 2.4 supplied with the instrument. $\mathrm{Cq}$ values of NBCs relative to a geometric mean from reference genes ACTB and 18S RNA were calculated, and fold changes relative to NBCel were determined using the $2^{-\Delta \Delta \mathrm{Cq}}$ method (36).

Immunoblotting. Cells were homogenized in ice-cold buffer (10 mM Tris- $\mathrm{HCl}, 150 \mathrm{mM} \mathrm{NaCl}, 1 \mathrm{mM}$ EDTA, $1 \%$ Triton $\mathrm{X}-100)$, supplemented with $1 \mathrm{x}$ protein inhibitor cocktail (Thermo Fisher Scientific, Inc.) and $1 \mathrm{mM}$ phenylmethylsulfonyl fluoride. Cells were centrifuged at $13,200 \mathrm{x} \mathrm{g}$ for $10 \mathrm{~min}$ at $4^{\circ} \mathrm{C}$ to remove cell debris and supernatants were collected. Protein concentration was determined using Bradford reagents (Millipore Sigma; Merck KGaA). A total of $15 \mu \mathrm{g}$ of proteins from samples were separated on a 
4-15\% SDS-polyacrylamide gel and blotted to a nitrocellulose membrane. The blot was incubated with mouse anti-human SLC4A4 monoclonal antibody (cat. no. sc-515543; Santa Cruz Biotechnology, Inc.) for $2 \mathrm{~h}$ at room temperature. The dilution was 1:500 with the blocking buffer (5\% nonfat dry milk and $0.05 \%$ Tween-20 in TBS). The blot was washed and incubated with a goat horseradish peroxidase-conjugated antibody to mouse IgG (1:1,000 dilution; cat. no. 12-349; Millipore Sigma; Merck $\mathrm{KGaA}$ ) for $2 \mathrm{~h}$ at room temperature. Immunoreactive bands were visualized using ECL chemiluminescence (Thermo Fisher Scientific, Inc.). The blot was striped and reprobed with rabbit anti-human $\beta$-actin polyclonal antibody (product code ab8227; 1:1,000 dilution; Abcam) for $1 \mathrm{~h}$ at room temperature. Densitometric analysis of immunoreactive bands was performed using ImageJ as previously described (37). $\mathrm{NBCe} 1$ pixel intensity was normalized to $\beta$-actin intensity after background subtraction.

Small interfering (si)RNA-mediated NBCel knockdown. Cells at the density of $1-2 \times 10^{4}$ were plated in 24 -well plates and transfected with siRNA oligonucleotides the following day. The siRNA 27-mer duplexes targeting human SLC4A4 (cat. no. SR305704) and the scrambled negative control duplex (cat. no. SR30004) were purchased from OriGene Technologies, Inc. (Table SII). Three SLC4A4 siRNA duplexes were pooled at equal concentrations for transfection (total 10 and $20 \mathrm{nM}$ ). Transfection was performed with Lipofectamine RNAiMax (Thermo Fisher) according to the manufacturer's instructions. After transfection, cells were incubated in hypoxia for $72-96 \mathrm{~h}$ in a $37^{\circ} \mathrm{C}$ incubator, and the efficacy of knockdown was determined by immunoblotting.

Lactate dehydrogenase $(L D H)$ release assay. Cell death was measured using the $\mathrm{LDH}$ release assay as previously described (38) with slight modification. Briefly, cells in 24-well plates were incubated with $1 \%$ Triton X-100 or water for $45 \mathrm{~min}$ and LDH released from cells was quantitated using CyQuant LDH Cytotoxicity Assay Kit (Thermo Fisher Scientific, Inc.). The amount of formazan produced by LDH-mediated NADH oxidation was determined by absorbances at 490 and $680 \mathrm{~nm}$ (background). Background absorbance at $680 \mathrm{~nm}$ was subtracted and absorbance in media only (no cells) was also subtracted. Cell death was calculated as a percentage of spontaneous LDH release to total LDH release.

Prostate cancer samples. The formalin-fixed, paraffinembedded human prostate carcinoma tissue microarrays containing 41 cases of prostate cancer and 9 cases of normal prostate tissue were purchased from US Biolab Corporation, Inc. (cat. no. PRO501). Information on pathology grade, Gleason grade, Gleason score, TNM classification and clinical stages are available on the company website. The purpose of using human tissue samples in this study was to examine the characteristics of cancerous tissue, not to develop treatments; thus, a respective Intuitional Review Board was not required for the use of the tissue microarrays in our study.

Sphere formation assay. A sphere formation assay was performed as previously described by Zhang et al (39) with slight modification. Falcon 8 -well chamber slides (product no. 354118; Corning, Inc.) were precoated with $50 \mu \mathrm{l}$ of LDEV-free growth factor-reduced Geltrex (cat. no. A1413201; Thermo Fisher Scientific, Inc.). Cells were plated at 3,000 cells/well in the aforementioned culture medium supplemented with $1 \%$ Geltrex. One day later, the cells were treated with 0 or $100 \mu \mathrm{M}$ of S0859 and incubated at $37^{\circ} \mathrm{C}$ for 6 days to form spheres. Images of spheres at a magnification of $\mathrm{x} 10$ were captured using a Keyence BZ-X700 fluorescence microscope (Keyence Corporation). To quantify sphere growth, the number of spheres was counted and Feret diameters were measured using the FIJI version of ImageJ.

Immunohistochemistry. The tissue microarrays were heated and subjected to deparaffinization in xylene, rehydration in graded series of ethanol, and rinsing with distilled water. The slides were then heat treated with the target retrieval solution DIVA Decloaker (Biocare Medical) using an electric pressure cooker for $20 \mathrm{~min}$. After washing, the slides were blocked with Background Sniper (Biocare Medical) at room temperature for $10 \mathrm{~min}$, washed and incubated with anti-NBCe1/SLC4A4 antibody (product no. HPA035628; Millipore Sigma; Merck $\mathrm{KGaA}$ ) diluted at 1:200 at $4^{\circ} \mathrm{C}$ overnight. The slides were washed and then incubated with MACH 2 Rabbit AP-Polymer (cat. no. RALP525; Biocare Medical) for $30 \mathrm{~min}$ at room temperature. The slides were stained with the chromogen solution Warp Red (BioCare Medical) at room temperature for $7 \mathrm{~min}$. Nuclei were counterstained with hematoxylin at room temperature for $45 \mathrm{sec}$. Digital images of stained slides were captured using a Biotek Lionheart FX microscope. The images were then evaluated by a histopathologist.

Statistical analysis. Data were reported as the mean \pm standard error of the mean (SEM). The significance of the difference between means was determined using: i) Unpaired, two-tailed Student's t-test for comparison of $\mathrm{dpH} / \mathrm{dt}$ and immunoblotting in normoxia vs. hypoxia, control vs. knockdown, and control vs. S0859 treatment; ii) paired, two-tailed Student's t-test for comparison of $\mathrm{dpH} / \mathrm{dt}$ before and after $\mathrm{Na}^{+}$addition, as well as S0859 sensitivity; iii) one-way ANOVA with Turkey post hoc test for comparison of NBC qPCR; and iv) two-way ANOVA with Fisher's LSD or Sidak post hoc test for comparison of viable cell number and cell death over time after S0859 treatment. $\mathrm{P}<0.05$ was considered to indicate a statistically significant difference. Analysis was performed using GraphPad Prism 7 (GraphPad Software, Inc.) and Microsoft Office Excel add-in Analysis ToolPak (Microsoft Corporation).

\section{Results}

$N B C$ expression levels are heterogenous in different prostate cancer cells. qPCR with primers specific to each member of NBCs was performed to determine their expression levels in human prostate cancer cell lines LNCaP, C4-2, PC3, 22RV1, DU145, and the prostate cell line RWPE-1. The expression ratios of each isoform relative to NBCel after being normalized to a geometric mean of reference genes ACTB and $18 \mathrm{~S}$ RNA is presented in Fig. 1A-F. Notably, NBCel expression levels were predominantly high in LNCaP cells and its subline C4-2 cells $(\mathrm{P}<0.01$ for both; $\mathrm{n}=4$ /group). NBCe1 expression was also observed in other cells, but its level was not 

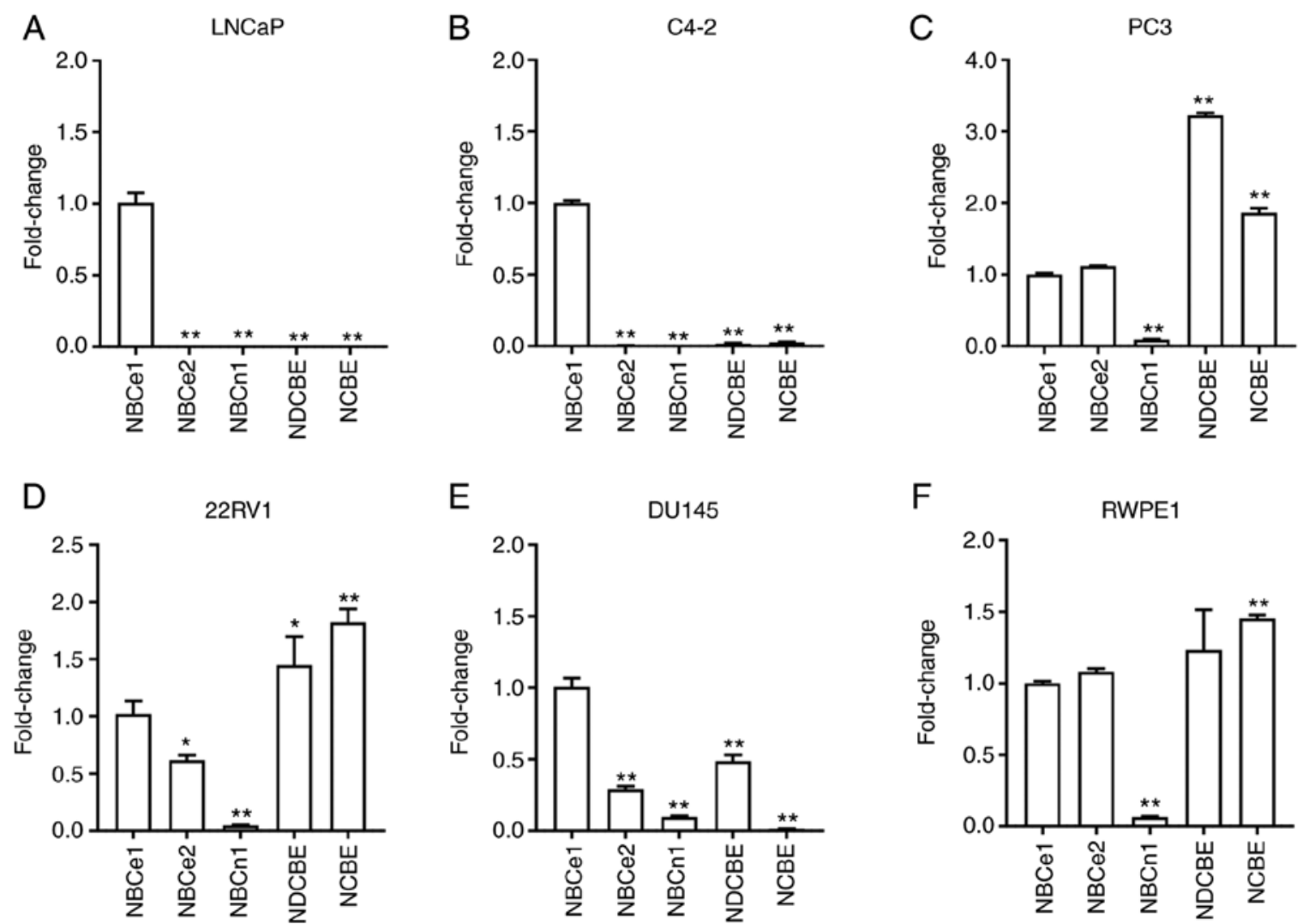

Figure 1. Sodium bicarbonate cotransporters NBCs in human prostate cancer cell lines. (A-F) Relative expression levels of NBCs in prostate cancer cells LNCaP, C4-2, PC3, 22RV1, DU145, and the prostate epithelial cell line RWPE-1 were determined by quantitative PCR. The expression level of each transporter was normalized to a geometric mean from reference genes ACTB and 18S RNA and presented as the fold change relative to NBCe1 expression level using the $2^{-\Delta \Delta C q}$ method $(n=4) .{ }^{*} \mathrm{P}<0.05$ and ${ }^{* *} \mathrm{P}<0.01$ compared to NBCe1.

predominant and detected together with NBCe2, NDCBE, NCBE and weakly with NBCn1. The expression profiles in PC3, 22RV1, and DU145 were to a certain extent similar to that in RWPE1. The comparison of NBCe1 expression levels among all six different cell lines is presented in Fig. 2. The level was significantly higher in LNCaP cells.

NBCel is responsible for acid extrusion in LNCaP cells. Because NBCel is highly abundant in LNCaP cells, this cell line was focused on for analysis of $\mathrm{Na} / \mathrm{HCO}_{3}$-dependent acid extrusion and its response to hypoxia. Immunoblotting data from cells incubated in normoxia vs. hypoxia $\left(1 \% \mathrm{O}_{2}\right.$, $5 \% \mathrm{CO}_{2}$ ) for 4 days are presented in Fig. 3A. NBCe1 was markedly upregulated in hypoxia. Densitometric quantitation of immunoreactive NBCe1 normalized to $\beta$-actin resulted in a 5.1-fold increase $(\mathrm{P}<0.01$, Student's t-test; $\mathrm{n}=3$; Fig. $3 \mathrm{~B})$. In parallel experiments, $\mathrm{pH}_{\mathrm{i}}$ measurement with the fluorescence dye BCECF was performed to assess whether acid extrusion is enhanced in hypoxia. The average $\mathrm{pH}_{\mathrm{i}}$ traces $\left(\mathrm{n}=11\right.$ cells/group) when cells were perfused with $5 \% \mathrm{CO}_{2}$, $28 \mathrm{mM} \mathrm{HCO}^{-}$(plus $100 \mu \mathrm{M}$ of amiloride to block endogenous NHEs) are presented in Fig. $3 \mathrm{C}$ and D. Comparison of $\mathrm{pH}_{\mathrm{i}}$ recovery rates resulted in a 3 -fold increase in hypoxia $\left(0.90 \pm 0.48 \times 10^{-4} \mathrm{dpH}_{\mathrm{i}} / \mathrm{sec}\right.$ in normoxia vs. $2.78 \pm 0.71 \times 10^{-4}$ $\mathrm{dpH}_{\mathrm{i}} / \mathrm{sec}$ in hypoxia; $\mathrm{P}<0.05$, Student's t-test; Fig. 3E). The properties of the $\mathrm{pH}_{\mathrm{i}}$ recovery from a $\mathrm{CO}_{2}$-induced acidification were further evaluated by assessing its $\mathrm{Na}^{+}$dependence and $\mathrm{S} 0859$ sensitivity. An average $\mathrm{pH}_{\mathrm{i}}$ recovery in the absence

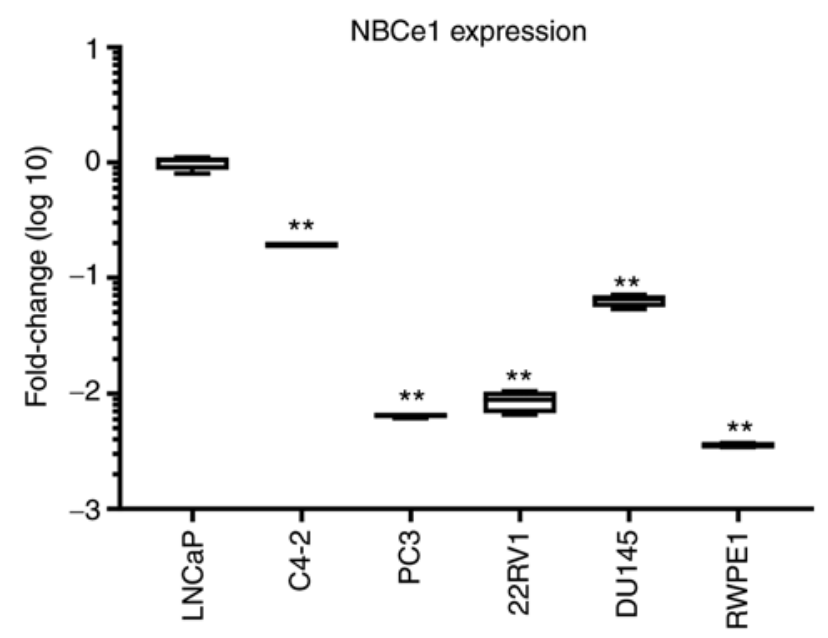

Figure 2. Relative expression of NBCe1 in different prostate cancer cell lines. $\mathrm{NBCe} 1$ expression levels in each cell type were calculated relative to that in LNCaP cells. Fold changes were presented in a logarithmic scale. ${ }^{* * *} \mathrm{P}<0.01$ compared to LNCaP cells.

and presence of $\mathrm{Na}^{+}(\mathrm{n}=11)$ is presented in Fig. 3F. The recovery was minimal in $\mathrm{Na}^{+}$-free $\mathrm{CO}_{2} / \mathrm{HCO}_{3}^{-}$solution, indicating that the major acid extrusion in $\mathrm{LNCaP}$ cells is dependent upon $\mathrm{Na}^{+}$. The recovery was increased when $\mathrm{Na}^{+}$was applied. The $\mathrm{dpH} / \mathrm{dt}$ in this $\mathrm{Na}^{+}$-containing solution was 5 -fold higher than the value in $\mathrm{Na}^{+}$-free solution $(\mathrm{P}<0.05$, paired Student's t-test; Fig. 3G), indicating that $\mathrm{Na} / \mathrm{HCO}_{3}$ transport largely 

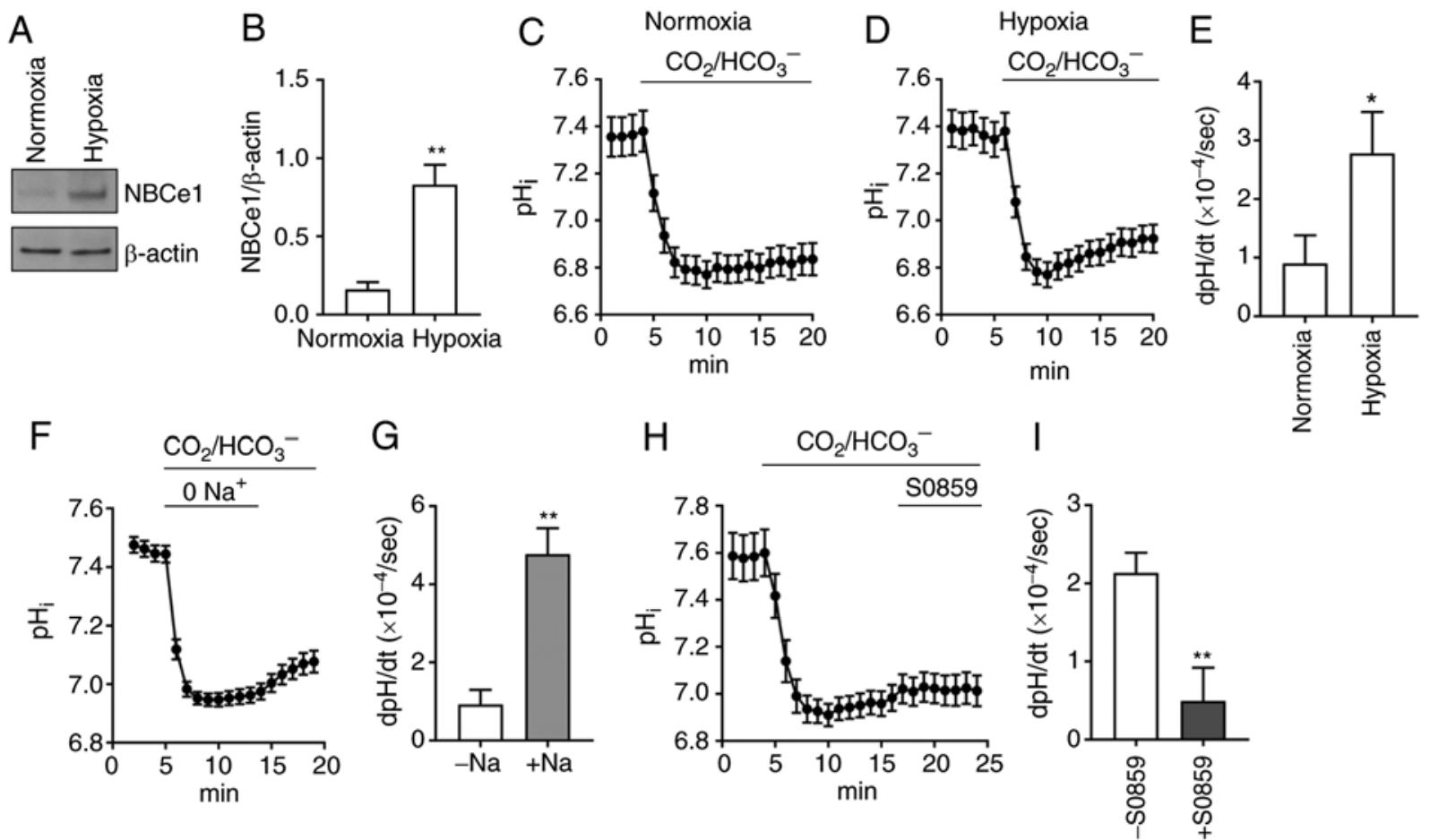

Figure 3. NBCe1-mediated acid extrusion in LNCaP cells. (A) NBCe1 immunoblot in LNCaP cells under normoxic vs. hypoxic conditions. Cells were incubated in normoxia or hypoxia $\left(1 \% \mathrm{O}_{2}, 5 \% \mathrm{CO}_{2}\right)$ for 4 days and subjected to immunoblotting with NBCe1 antibody. The blot was then striped and reprobed with $\beta$-actin antibody. (B) Densitometric measurements of NBCe1 expression. The intensity of immunoreactive NBCe1 was normalized to that of $\beta$-actin (n=3). (C and D) $\mathrm{HCO}_{3}^{-}$-dependent acid extrusion in normoxia vs. hypoxia. Cells were exposed to a solution containing $5 \% \mathrm{CO}_{2}, 28 \mathrm{mM} \mathrm{HCO}_{3}^{-}$, and the $\mathrm{pH}_{\mathrm{i}}$ was recorded using the $\mathrm{pH}$ fluorescence dye $\mathrm{BCECF}$ ( $\mathrm{n}=11$ cells/group). (E) Rate of $\mathrm{pH}_{\mathrm{i}}$ recovery $\left(\mathrm{dpH} / \mathrm{dt}\right.$ ). Recovery from a $\mathrm{CO}_{2}$-induced acidification presented in $\mathrm{C}$ and $\mathrm{D}$ was analyzed and the rate $\left(\mathrm{dpH} / \mathrm{sec} \times 10^{-4}\right)$ was determined during the first 4 min of recovery. $(\mathrm{F}) \mathrm{Na}^{+}$dependence of $\mathrm{pH}_{\mathrm{i}}$ recovery. Cells in hypoxia were exposed to $\mathrm{Na}^{+}$-free $\mathrm{CO}_{2} / \mathrm{HCO}_{3}^{-}$solution and then to $\mathrm{Na}^{+}$-containing solution ( $\mathrm{n}=11$ ). (G) Comparison of dpH/dt in $\mathrm{Na}^{+}$-free vs. $\mathrm{Na}^{+}$-containing solutions . (H) Inhibition of $\mathrm{pH}_{\mathrm{i}}$ recovery by $50 \mu \mathrm{M}$ of S0859. (I) Comparison of $\mathrm{dpH} / \mathrm{dt}$ in the absence vs. presence of $\mathrm{S} 0859$ ( $\mathrm{n}=>16$ cells $/$ group). ${ }^{*} \mathrm{P}<0.05$ and ${ }^{* *} \mathrm{P}<0.01$. BCECF, 2,7-bis(2-carboxyethyl)-5(6)-carboxyfluorescein acetoxymethyl ester.

governs acid extrusion in hypoxia. In other experiments, the sensitivity to the $\mathrm{Na} / \mathrm{HCO}_{3}$ inhibitor $\mathrm{S} 0859(50 \mu \mathrm{M})$ was examined (Fig. 3H). This concentration was selected based on a previous study (40) where $\mathrm{S} 0859$ at $>30 \mu \mathrm{M}$ fully inhibited NBCs in cardiomyocytes. Comparison of $\mathrm{pH}_{\mathrm{i}}$ recoveries in the absence vs. presence of S0859 revealed a significant inhibition by the drug. The average inhibition was $77 \%(\mathrm{P}<0.01$, Student's t-test; $\mathrm{n}=16$ cells/group; Fig. 3I). Collectively with the predominant expression of $\mathrm{NBCe} 1$, these $\mathrm{pH}_{\mathrm{i}}$ data demonstrated that NBCel plays a major role in acid extrusion in LNCaP cells.

$N B C e 1$ contributes to $L N C a P$ cell proliferation and viability. To examine whether NBCel affects growth and survival of LNCaP cells, NBCel gene expression was disrupted using siRNA oligonucleotides. The knockdown efficacy determined by immunoblotting $96 \mathrm{~h}$ after transfection is presented in Fig. 4A. Compared to the control siRNA/random 27-mers, the siRNA/NBCe1 decreased NBCe1 protein levels by over $90 \%$ $(\mathrm{P}<0.01$, Student's t-test; $\mathrm{n}=3$; Fig. 4B). In parallel experiments, the number of viable cells in the trypan blue exclusion assay was counted. As shown in Fig. 4C, the knockdown decreased the number of viable cells by $54 \%$ (from $2.4 \times 10^{5}$ cells $/ \mathrm{ml}$ to $1.1 \times 10^{5}$ cells $/ \mathrm{ml} ; \mathrm{P}<0.01 ; \mathrm{n}=6 /$ group) when determined at 4 days after treatment. The cell viability (i.e., percentage of viable cell to total cells) was also decreased, but the magnitude of the change was relatively small (13\%; $\mathrm{P}<0.01$; Fig. 4D), implying that the decrease in cell number is not tightly related to the decrease in viability. Consistent with this implication, the knockdown caused $10-12 \%$ cell death, determined by the LDH release assay ( $n=5$ at $10 \mathrm{nM}$ and $\mathrm{n}=6$ at $20 \mathrm{nM}$ of siRNA/NBCe1), markedly smaller than the percent change in cell number (Fig. 4E). Doubling the amounts of siRNA/NBCe1 oligonucleotides for transfection did not further increase the cell death $(\mathrm{P}>0.05)$, indicating that the knockdown has reached a maximum level of cell death.

Next, LNCaP cells were treated with $50 \mu \mathrm{M}$ of $\mathrm{S} 0859$ to assess whether pharmacological inhibition of NBCel produces similar effects. As shown in Fig. 5A, S0859 treatment decreased the number of viable cells $(23 \%$ at 4 days after treatment, $\mathrm{P}<0.01, \mathrm{n}=15$ /group; and $19 \%$ at 6 days after treatment, $\mathrm{P}<0.05$, $n=6 /$ group). These decreases were smaller than the decrease by the aforementioned NBCe1 knockdown. Furthermore, cell death was not observed at 4 days after treatment but increased at 6 days after treatment (Fig. 5B). Consistent with this lack of cell death at 4 days after treatment, the viability was unchanged during the same treatment days (Fig. 5C) and NBCel protein levels were also unaltered (Fig. 5D and E). Thus, the pharmacological inhibition of NBCel decreases cell proliferation, similar to the knockdown, but the two methods appear to have different mechanisms affecting cell death.

NBCel contributes to PC3 cell proliferation and viability. The qPCR results revealed the most exclusively abundant 
A

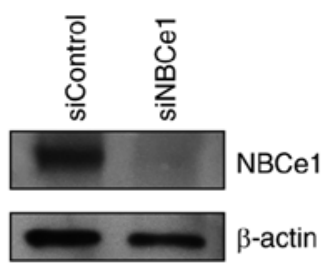

B

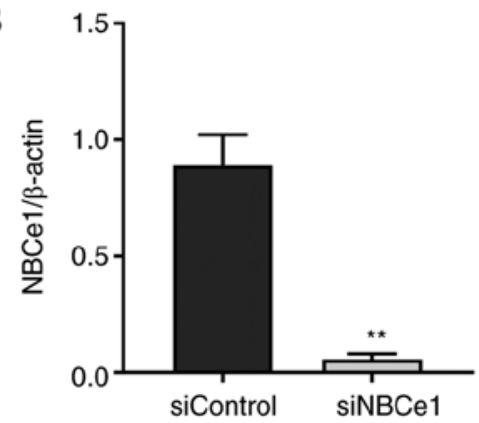

C

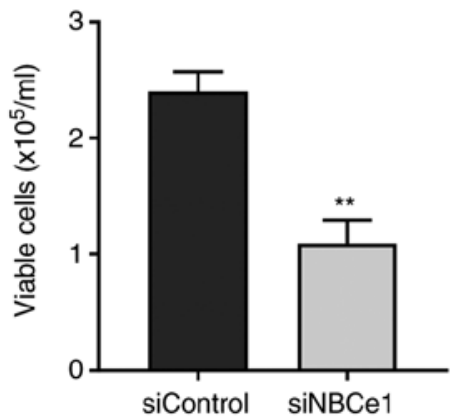

D

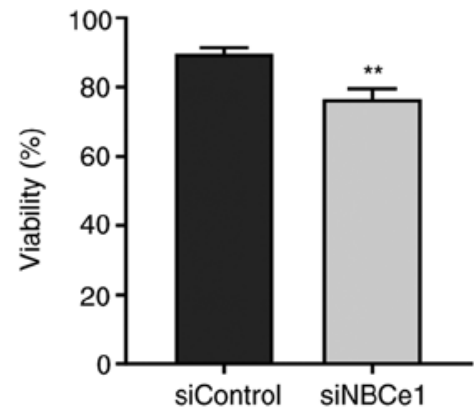

E

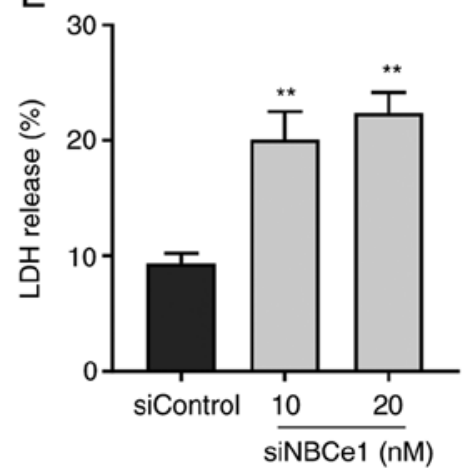

Figure 4. Decreased LNCaP cell proliferation by NBCe1 knockdown. (A) Immunoblot of NBCe1 in cells treated with siRNA/random 27-mers control and siRNA/NBCe1 knockdown. Cell lysates were collected 4 days after treatment and subjected to immunoblotting. (B) Densitometric measurements of NBCe1 expression. NBCe1 intensity was normalized to $\beta$-actin intensity $(n=3)$. (C) Number of viable cells after NBCe1 knockdown. Viable cells were counted using the trypan blue exclusion assay ( $\mathrm{n}=6 /$ group). (D) Cell viability after knockdown. Viability was calculated by percentage of live cell numbers to total cell numbers (live cells + dead cells) in the trypan blue exclusion assay. (E) Cell death after NBCe1 knockdown. Cell death was determined by percentage of spontaneous LDH release to total LDH release ( $\mathrm{n}=11$ control, 5 knockdown at $10 \mathrm{nM}$ and 6 knockdown at $20 \mathrm{nM}$ ). ${ }^{* *} \mathrm{P}<0.01$. siRNA, small interfering; $\mathrm{LDH}$, lactate dehydrogenase.

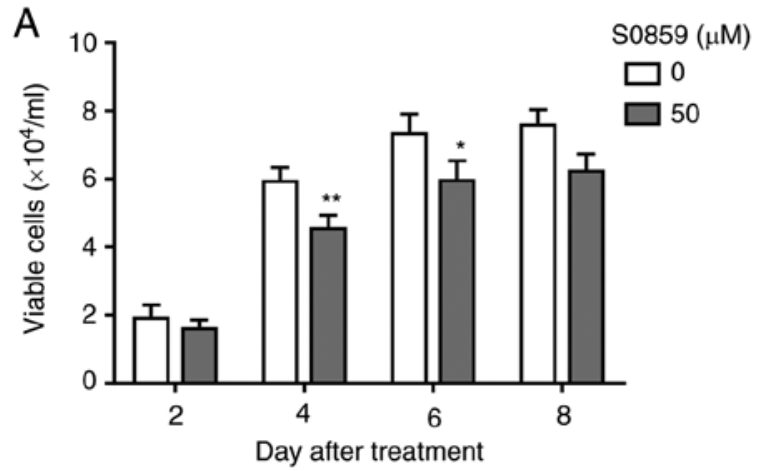

C

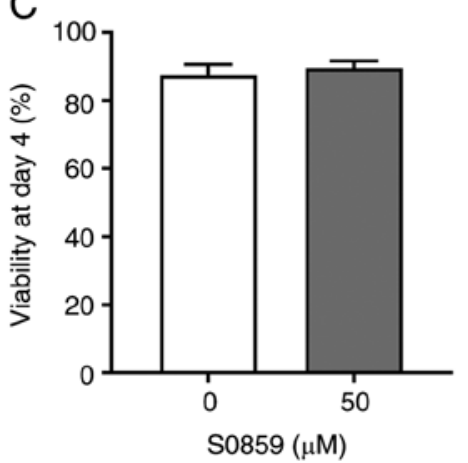

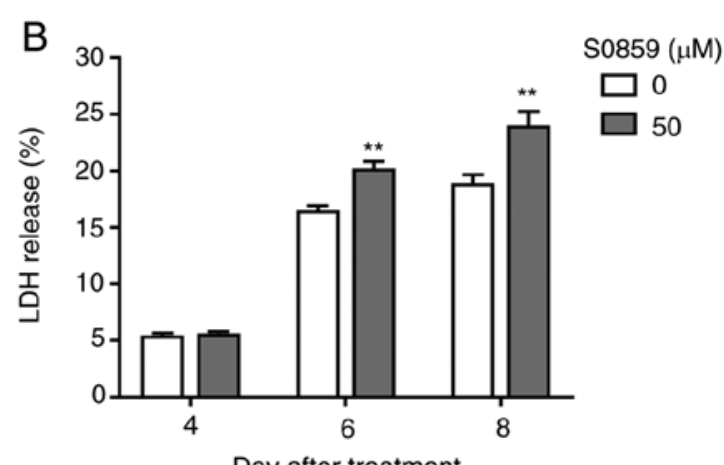

Day after treatment

$\mathrm{E}$

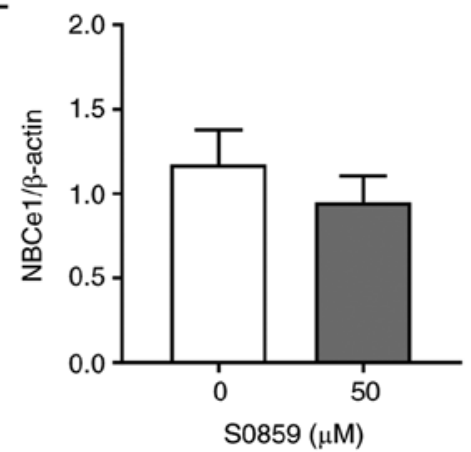

Figure 5. Decreased LNCaP cell growth by S0859. (A) Number of viable cells after S0859 treatment. Cells were treated with $50 \mu \mathrm{M}$ of S0859 or none and viable cells were counted in the trypan blue exclusion assay ( $\mathrm{n}=4$ /group for each day). (B) Cell death after $\mathrm{S} 0859$ treatment. LDH release assays were performed at days 4, 6 and 8 after treatment (n=3-9/group). (C) Cell viability at 4 days after S0859 treatment ( $\mathrm{n}=4$ /group). (D) Immunoblot of NBCe1 in cells treated with S0859. Cells were incubated with $50 \mu \mathrm{M}$ of S0859 for 4 days and subjected to immunoblotting. (E) Densitometric measurements of NBCe1 immunoblot. NBCe1 was normalized to $\beta$-actin $(n=6)$. ${ }^{*} \mathrm{P}<0.05$ and $^{* *} \mathrm{P}<0.01$. $\mathrm{LDH}$, lactate dehydrogenase. 
A
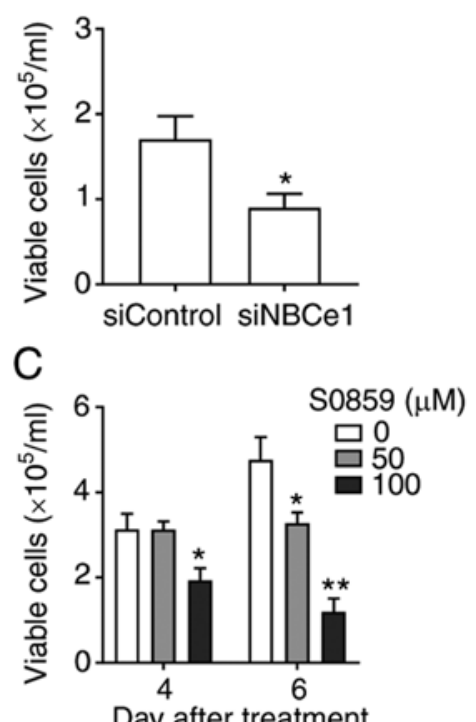

B

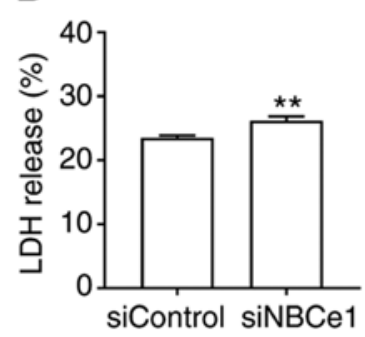

$\mathrm{D}$

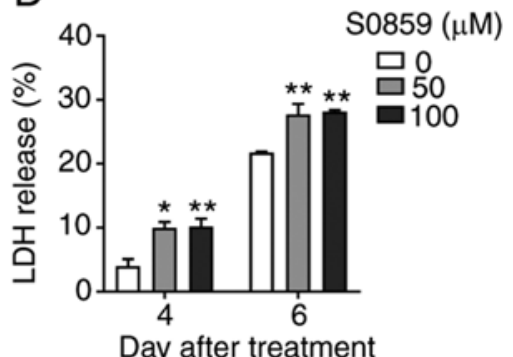

Figure 6. Decreased PC3 cell proliferation by NBCe1 knockdown and inhibition. (A) Number of viable cells after NBCe1 knockdown. Viable cells were counted 4 days after treatment with siRNA oligonucleotides ( $\mathrm{n}=6 /$ group). (B) Cell death after NBCe1 knockdown. LDH release assays were performed on the same day (n=6-8/group). (C) Number of viable cells after S0859 treatment. PC3 cells were treated with 50 and $100 \mu \mathrm{M}$ of S0859 or none (n=4/group). (D) Cell death after S0859 treatment ( $\mathrm{n}=4$ /group). ${ }^{*} \mathrm{P}<0.05$ and ${ }^{* *} \mathrm{P}<0.01$. siRNA, small interfering; LDH, lactate dehydrogenase.

A
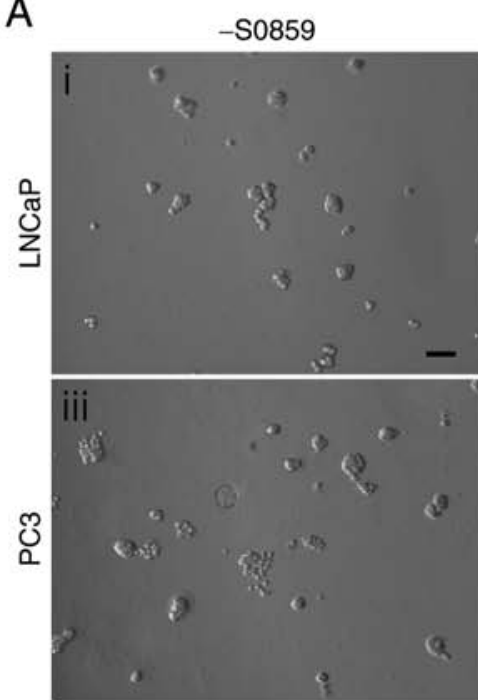

+ S0859
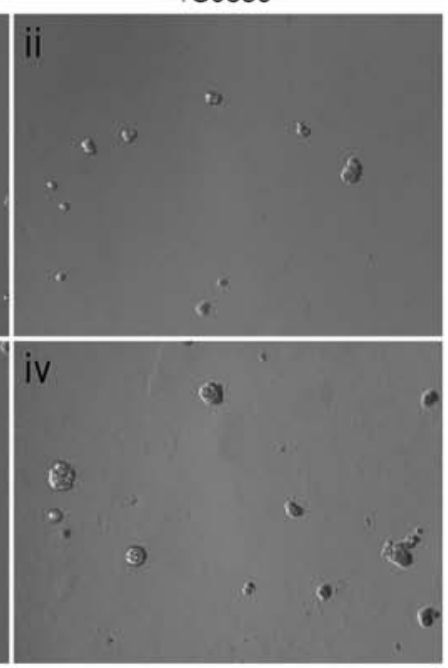

B

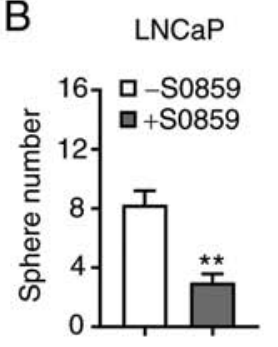

D

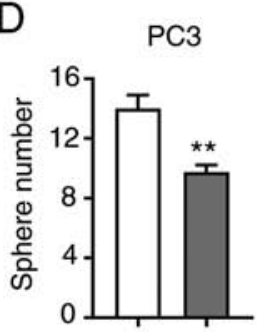

C LNCaP

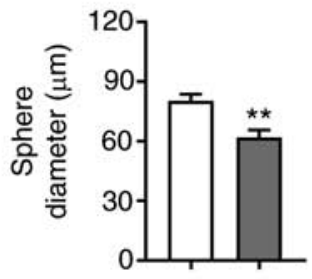

$\mathrm{E}$

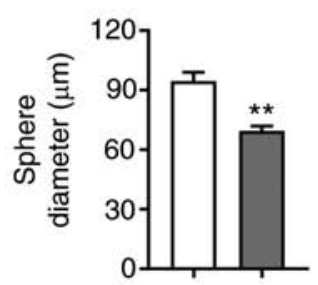

Figure 7. Decreased LNCaP and PC3 cell sphere formation by S0859 in 3D cultures. (A) Representative bright-field images of LNCaP and PC3 cell spheres in the absence and presence of S0859. Cells were cultured in serum-free, growth factor-reduced Geltrex with 0 or $100 \mu \mathrm{M}$ of S0859 for 6 days (n=3-6/group). The scale bar in image i is $100 \mu \mathrm{m}$ and applies to all images. (B and D) Number of spheres formed. Spheres were randomly captured at a magnification of x10 and counted per captured image. Spheres containing minimum $5 \mathrm{LNCaP}$ cells and 10 PC 3 cells were analyzed for comparison ( $\mathrm{n}=4 / \mathrm{group}$ ). (C and E) Quantitation of sphere growth. Sphere growth was quantitated by measuring sphere Feret diameters using Image ( $\mathrm{n}=13-34 \mathrm{LNCaP}$ cell spheres and 39-56 PC3 cell spheres). ${ }^{* *} \mathrm{P}<0.01$.

expression of $\mathrm{NBCe} 1$ in $\mathrm{LNCaP}$ and $\mathrm{C} 4-2$ cells, but moderate co-expression with other NBCs in cells such as PC3. This leads to the possibility that NBCel contribution to cell proliferation and viability may vary depending upon cell types. To address this possibility, NBCe1 knockdown was performed in PC3 cells and cell numbers were counted. As shown in Fig. 6A, the knockdown decreased the number of viable cells by $48 \%$ (from $1.71 \times 10^{5}$ to $0.89 \times 10^{5}$ cells $/ \mathrm{ml}$ at 4 days after transfection; $\mathrm{P}<0.05, \mathrm{n}=9 /$ group). The knockdown also caused a small increase in cell death (3\%; Fig. 6B). Thus, NBCe1 affected the growth and viability of PC3 cells, similar to those in LNCaP cells. Next, cells were treated with S0859, which should inhibit all NBCs, and viable cell number and cell death at 4 days after treatment were assessed. Interestingly, S0859 had no effect at $50 \mu \mathrm{M}$ but decreased viable cell numbers at $100 \mu \mathrm{M}(38 \%$ decrease; $\mathrm{P}<0.05$, $\mathrm{n}=4$ /group; Fig. $6 \mathrm{C}$ ). The decrease was more severe at 6 days after treatment $(31 \%$ decrease at $50 \mu \mathrm{M}$ and $75 \%$ decrease at $100 \mu \mathrm{M} ; \mathrm{P}<0.01$ for both, $\mathrm{n}=3-8 /$ group). As 

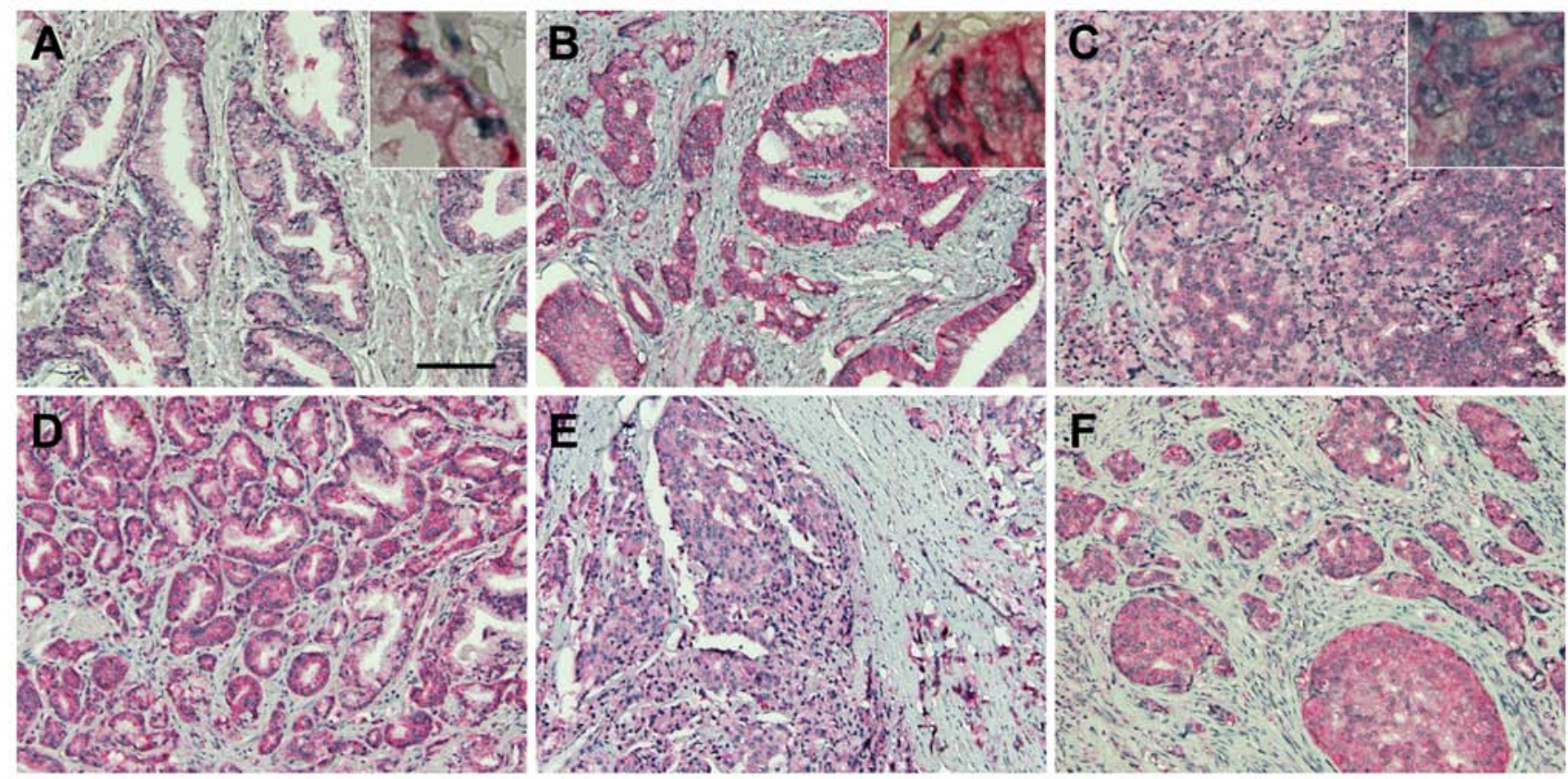

Figure 8. Immunohistochemical analysis of NBCe1 in human prostate tissue and prostatic adenocarcinoma. (A) NBCe1 staining in prostatic glandular epithelia. Basolateral localization of NBCe1 is shown in an inset (magnification, $\mathrm{x} 60$ ). (B and C) NBCe1 staining in acinar adenocarcinoma in Gleason grades (B) 3 and (C) 4. Robust NBCe1 staining in carcinoma was detected while its plasma membrane localization was progressively lost in higher Gleason grades (inset), consistent with the lost ability of cancer cells to form glands. (D-F) NBCe1 staining in duct adenocarcinoma. The Gleason grades are (D) 3 , (E) 4 and (F) 5 . Representative images were selected from 9 normal prostates, 10 acinar adenocarcinoma and 24 duct adenocarcinoma in tissue microarrays. The scale bar in $\mathrm{A}$ is $200 \mu \mathrm{m}$ and applies to all images.

anticipated, S0859 caused a small increase cell death $(6 \%$ at both concentrations; Fig. 6D). A higher amount of S0859 was required to decrease the proliferation of PC3 cells, in comparison to LNCaP cells. Conclusively, NBCe1 knockdown in PC3 cells decreased cell proliferation to the level similar to that by the same knockdown in LNCaP cells, indicating that NBCel significantly affects PC3 cell growth.

S0859 decreases LNCAP and PC3 cell spheres in 3D cultures. The effects of $\mathrm{NBC}$ inhibition on $\mathrm{LNCaP}$ and $\mathrm{PC} 3$ cell growth were further examined in 3D cultures. The images of cell spheres formed 6 days after treatment with $100 \mu \mathrm{M}$ of S0859 or none are presented in Fig. 7A. Compared to the control, S0859 decreased sphere formation in both cell lines. The number of LNCaP cell spheres was decreased by $64 \%(\mathrm{P}<0.01$, n=4/group; Fig. 7B) and the Feret diameter was decreased by $23 \%(\mathrm{P}<0.01, \mathrm{n}=13-34$ spheres/group; Fig. 7C). Similarly, the number of PC3 cell spheres was decreased by $31 \%(\mathrm{P}<0.01$, $\mathrm{n}=4$ /group; Fig. 7D) and the Feret diameter was decreased by $27 \%(\mathrm{P}<0.01, \mathrm{n}=39-56$ spheres/group; Fig. 7E). Thus, similar as in 2D cultures, pharmacological inhibition of NBCe1 reduces LNCaP and PC3 cell growth in 3D cultures.

NBCel expression is robust in prostatic adenocarcinoma. The robust expression of $\mathrm{NBCe} 1$ in $\mathrm{LNCaP}$ cells led us to a localization study of this transporter in human prostate tissue and prostatic cancer. For this experiment, NBCe1 immunohistochemistry was performed on human prostate cancer tissue microarrays containing 9 cases of normal prostate tissue and 41 cases of prostate cancer (aforementioned in the Materials and methods). NBCel was localized to the basolateral side of the glandular epithelial cells in normal prostate
(Fig. 8A), consistent with its basolateral localization in a variety of secretory glands (11). In prostatic cancer, NBCe1 was highly abundant in adenocarcinoma in Gleason grades 3-5 (Fig. 8B-F). The plasma membrane staining progressively disappeared in higher Gleason grades, consistent with the lost ability of cancer cells to form glands in more advanced tumor stages.

\section{Discussion}

The significance and novelty of our study are as follows: i) Despite reports on multiple acid extrusion mechanisms and their involvement in cancer cell growth and progression, no investigation has been made on prostate cancer. Our study, for the first time, provides an expression profile of NBCs among different prostate cancer cell lines. ii) NBCel knockdown and inhibition decrease LNCaP and PC3 cell proliferation and viability. The decrease in PC3 cell growth by the knockdown is notable given that PC3 cells possess other NBCs in addition to NBCe1. This further indicates that, among different NBCs, NBCel is the key transporter affecting cell proliferation. iii) NBCe1 is extensively expressed in human prostate adenocarcinoma. The result provides important immunohistochemical evidence of NBCel expression/localization in human prostate tissue and prostatic cancer.

In this study, high expression of NBCel was identified in $\mathrm{LNCaP}$ and $\mathrm{C} 4-2$ cells, but weak to moderate expression in PC3, 22RV1 and DU145 cells. The latter cells also express other NBCs in addition to NBCe1. LNCaP and 22RV1 are androgen-responsive and their growth is inhibited by androgen withdrawal, whereas C4-2, PC3, DU145 are androgen-irresponsive and their growth is independent 
of androgen (41). Thus, the expression of NBCs including $\mathrm{NBCe} 1$ does not correlate with androgen responsiveness in these cells. It is interesting to note that neuron-specific NDCBE and NCBE are expressed in PC3, 22RV1 and DU145 cells. Tai et al (42) have reported that LNCaP cells are similar to adenocarcinoma characterized by lack of basal cells and proliferation of malignant tumor cells with luminal differentiation, whereas PC 3 cells are characteristic of neuroendocrine carcinoma. In our study, NBCe1 upregulation was observed in $\mathrm{LNCaP}$ cells under hypoxic conditions. Literature search and database analysis have revealed a similar upregulation in prostate cancer $(30,31)$. NBCe1 was one of the gene products stimulated in a mouse model of prostate cancer developed by a deletion of the tumor suppressor gene Atbfl (30). The increase was 1.7-1.8 fold in mRNA expression; nonetheless, NBCe1 was the only NBC that was increased in response to cancer development and other NBCs were unaffected. The human genome array database in the Oncomine Research (www.oncomine.org) revealed NBCel mRNA upregulation in prostate carcinoma. The increase was 2.1-fold, but it was ranked in top $1 \%$ among 8,603 measured genes. Furthermore, a whole-genome sequencing of 27 prostate cancer patients revealed a focal amplification of SLC4A4 gene (31). The amplification occurred only $15 \%$ among patients, but the result supports the idea that excessive NBCe1 activity may accelerate extracellular acidification and promote microenvironments favorable for cancer growth.

By what mechanism would $\mathrm{NBCe} 1$ be upregulated? NBCel upregulation is dependent on the hypoxia-inducing factor $1 \alpha(H I F 1 \alpha)$ in LS174T colon cancer cells (21). HIF1 $\alpha$ primarily promotes glucose consumption and glycolysis in control of cell metabolism, whereas HIF $2 \alpha$ promotes fatty acid storage (43). HIF1 $\alpha$ involvement in NBCe1 upregulation implies that the upregulation is an upstream event from the transporter's response to intracellular acid load. Thus, while the upregulation offers an advantage when cancer cells actively proliferate with a high rate of metabolic acid production, intracellular acid load itself is unlikely the prime cause of this upregulation. NBCel gene expression was stimulated by the TGF- $\beta / \mathrm{Smad} 4$ signaling in mouse astrocytes (44). Given that TGF- $\beta / \mathrm{Smad} 4$ regulates proto-oncogene Src (45), a non-receptor tyrosine kinase associated with advanced malignancy in human cancers, it is notable that NBCe1 is stimulated by Src (46).

NBCe1 knockdown decreased the proliferation of both LNCaP and PC3 cells. The effects were substantial as the cell numbers were decreased by $48-54 \%$. The knockdown also decreased cell death; however, the magnitude of change was relatively small (3-13\%). There is not enough information on the cellular mechanisms underlying NBCel involvement in cell proliferation and cytotoxicity in other cells, and this makes it difficult to apprehend the molecular events following NBCe1 knockdown. Nonetheless, it is noteworthy that NBCe1 binds to IRBIT ( $\mathrm{IP}_{3}$ receptor-binding protein released with $\mathrm{IP}_{3}$ ), which regulates intracellular $\mathrm{Ca}^{2+}$ release from $\mathrm{IP}_{3}$ receptor $(47,48)$. IRBIT is involved in cell death by binding to Bcl2110 and facilitating massive $\mathrm{Ca}^{2+}$ transfer to mitochondria (49). Thus, it is possible that NBCe1 knockdown redistributes IRBIT in the cytosol, such that its capacity to interact with Bcl2110 is enhanced. Similar to the knockdown, prolonged treatment of
S0859 also decreased the growth of LNCaP and PC3 cells, consistent with its effects in other cancer cell lines $(20,21,50)$. S0859 was more potent in LNCaP than PC 3 cells, because the treatment at $50 \mu \mathrm{M}$ decreased viable $\mathrm{LNCaP}$ cell numbers but had no effect on PC 3 cells when measured 4 days after treatment. A higher concentration was required to alter PC3 cell numbers. S0859 also increased cell death in both cell types, but the change was relatively small compared to its effects on cell growth. Thus, S0859 primarily inhibits cell proliferation, rather than cell death in prostate cancer cells.

$\mathrm{Na}^{+}$and $\mathrm{HCO}_{3}{ }^{-}$-dependent acid extrusion was identified in $\mathrm{LNCaP}$ cells, confirming the expression of active NBCe1 in these cells. In our study, $\mathrm{S} 0859$ at $50 \mu \mathrm{M}$ inhibited $\mathrm{pH}_{\mathrm{i}}$ recovery from acidification by $77 \%$. Heidtmann et al (51) have reported that, in voltage clamp recordings of Xenopus oocytes expressing NBCe1, S0859 at this concentration inhibited $90 \%$ of the electrogenic current $\left(\mathrm{IC}_{50}\right.$ of $\left.9 \mu \mathrm{M}\right)$. The authors also observed an $80 \%$ inhibition of the current in mouse astrocytes, in which NBCe1 is highly expressed (52). Thus, the percent inhibition that was observed in LNCaP cells is comparable to the inhibitions in NBCe1-expressing oocytes and native astrocytes. The high level of inhibition further suggests that NBCe1 plays a major role in acid extrusion in $\mathrm{LNCaP}$ cells while other acid-extruding transporters are minimally involved. S0859 has been reported to inhibit MCTs in the Xenopus oocyte expression (51). In our experiment, the $\mathrm{pH}_{\mathrm{i}}$ recovery in $\mathrm{Na}^{+}$-free $\mathrm{CO}_{2} / \mathrm{HCO}_{3}{ }^{-}$solution was small, indicating that acid extrusion in LNCaP cells is largely $\mathrm{Na}^{+}$-dependent. This further suggests that MCTs play a minor role in LNCaP cells. Hypoxia-inducible MCT4 was relatively low in $\mathrm{LNCaP}$ cells, compared to $\mathrm{PC} 3$ as well as RWPE-1 and WPE1 prostate epithelial cell lines (53).

The results from our study lead to a discussion on a possible role of NBCe1 in human prostate cancer. Prostatic glandular epithelial cells are proliferated to premalignant prostate intraepithelial neoplasia (PIN) that consequently develops into intraductal carcinoma and invasive prostate cancer. Hypoxia and acidosis are induced in PIN as cell proliferation occurs, and HIF1 $\alpha$ is activated (54). HIF1 $\alpha$ promotes NBCe1 upregulation along with other acid extrusion proteins such as NHEs $(25,55)$, V-ATPases (26) and MCTs (28). Membranebound CA IX is also upregulated (56). The upregulation of these proteins moves $\mathrm{HCO}_{3}{ }^{-}$from cell surfaces to the inside of cancer cells and leaves $\mathrm{H}^{+}$at the outer side of the membrane, and acidic microenvironments are exacerbated. Extracellular acidification is additionally facilitated via a molecular interaction between NBCe1 and CA IX (57). Consequently, acidic microenvironments promote cancer cell survival and proliferation (33). In addition, NBCe1 may contribute to cancer cell migration and invasion because this transporter is capable of facilitating cell migration in colon and breast cancer cell lines (20). The migration may occur in collaboration with NHE1, which is concentrated at the leading edge of the lamellipodium and contributes to cell migration (58).

In summary, the present study demonstrates the importance of NBCel for acid extrusion in prostate cancer cells and its contribution to cell growth. The decreased cell proliferation and viability by NBCe1 knockdown and inhibition are in good agreement with the current understanding that disrupting intracellular acid-base homeostasis suppresses cancer cell growth 
and progression $(7,8)$. $\mathrm{NBCe} 1$ is proposed as a potential target protein for a hypoxia-activated prodrug that is delivered to hypoxic regions and kills cancer cells (59). In addition, given risks of prostate cancer and systemic $\mathrm{pH}$ disturbance with age (60), our study may provide a basis for future investigation of a pathological connection between the two age-related health issues. The present study was performed in cell culture models and additional assessments are required to confirm the involvement of NBCe1 in cancer cell growth in vivo. Thus, a future study will be to test whether abolishing or inhibiting $\mathrm{NBCel}$ reduces prostate cancer growth in animal models.

\section{Acknowledgements}

We thank Dr Wei Zhou and Dr Carlos Moreno for providing prostate cell lines and Dr Deepa Kodandera at the Emory Yerkes Histology and Molecular Pathology Laboratory for immunohistochemistry. We also thank Dr Baotong Zhang for technical advice on 3D culture and Dr Thomas Chun for discussion about human prostate cancer treatment and prevention. Reda Zafar is a medical student at Tuoro College of Osteopathic Medicine, New York and participated in the study as a summer intern.

\section{Funding}

This work was supported in part by Emory University Winship Cancer Pilot Grant no. 00068255 (IC).

\section{Authors' contributions}

All the authors contributed to the conception and design of the study. JML, SL, RZ and IC acquired the data. JML, SL, RZ, ES analyzed and interpreted the data. ES drafted the manuscript. ES and IC critically revised the manuscript for important intellectual content. All authors read and approved the final manuscript.

\section{Availability of data and materials}

The datasets used and/or analyzed during the current study are available from the corresponding author on reasonable request.

\section{Ethics approval and consent to participate}

The formalin-fixed, paraffin-embedded human prostate carcinoma tissue microarrays containing 41 cases of prostate cancer and 9 cases of normal prostate tissue were purchased from US Biolab Corporation, Inc. All tissues were collected under the highest ethical standards with the donor being informed completely and with their consent.

\section{Patient consent for publication}

Not applicable.

\section{Competing interests}

The authors declare that they have no competing interests.

\section{References}

1. Boron WF: Regulation of intracellular pH. Adv Physiol Educ 28: 160-179, 2004.

2. Parks SK, Cormerais Y and Pouyssegur J: Hypoxia and cellular metabolism in tumour pathophysiology. J Physiol 595: 2439-2450, 2017

3. Corbet $\mathrm{C}$ and Feron $\mathrm{O}$ : Tumour acidosis: From the passenger to the driver's seat. Nat Rev Cancer 17: 577-593, 2017.

4. Svastová E, Hulíková A, Rafajová M, Zat'ovicová M, Gibadulinová A, Casini A, Cecchi A, Scozzafava A, Supuran CT, Pastorek J and Pastoreková S: Hypoxia activates the capacity of tumor-associated carbonic anhydrase IX to acidify extracellular pH. FEBS Lett 577: 439-445, 2004.

5. Pastorekova $S$ and Gillies RJ: The role of carbonic anhydrase IX in cancer development: Links to hypoxia, acidosis, and beyond. Cancer Metastasis Rev 38: 65-77, 2019.

6. Webb BA, Chimenti M, Jacobson MP and Barber DL: Dysregulated pH: A perfect storm for cancer progression. Nat Rev Cancer 11: 671-677, 2011.

7. Fais S, Venturi G and Gatenby B: Microenvironmental acidosis in carcinogenesis and metastases: New strategies in prevention and therapy. Cancer Metastasis Rev 33: 1095-1108, 2014.

8. Parks SK and Pouysségur J: Targeting $\mathrm{pH}$ regulating proteins for cancer therapy-Progress and limitations. Semin Cancer Biol 43: 66-73, 2017.

9. Choi I: SLC4A transporters. Curr Top Membr 70: 77-103, 2012.

10. Aalkjaer C, Boedtkjer E, Choi I and Lee S: Cation-coupled bicarbonate transporters. Compr Physiol 4: 1605-1637, 2014.

11. Parker MD and Boron WF: The divergence, actions, roles, and relatives of sodium-coupled bicarbonate transporters. Physiol Rev 93: 803-959, 2013.

12. Liu Y, Yang J and Chen LM: Structure and function of SLC4 family HCO-3 transporters. Front Physiol 6: 355, 2015.

13. Gatenby RA and Gillies RJ: A microenvironmental model of carcinogenesis. Nat Rev Cancer 8: 56-61, 2008.

14. Lee D and Hong JH: The fundamental role of bicarbonate transporters and associated carbonic anhydrase enzymes in maintaining Ion and $\mathrm{pH}$ homeostasis in non-secretory organs. Int J Mol Sci 21: 339, 2020.

15. Ahmed S, Thomas G, Ghoussaini M, Healey CS, Humphreys MK, Platte R, Morrison J, Maranian M, Pooley KA, Luben R, et al: Newly discovered breast cancer susceptibility loci on 3p24 and 17q23.2. Nat Genet 41: 585-590, 2009.

16. Boedtkjer E, Moreira JM, Mele M, Vahl P, Wielenga VT, Christiansen PM, Jensen VE, Pedersen SF and Aalkjaer C: Contribution of $\mathrm{Na}+\mathrm{HCO} 3(-)$-cotransport to cellular $\mathrm{pH}$ control in human breast cancer: A role for the breast cancer susceptibility locus NBCn1 (SLC4A7). Int J Cancer 132: 1288-1299, 2013.

17. Gorbatenko A, Olesen CW, Loebl N, Sigurdsson HH, Bianchi C, Pedraz-Cuesta E, Christiansen J and Pedersen SF: Oncogenic p95HER2 regulates Na+-HCO3- cotransporter NBCn1 mRNA stability in breast cancer cells via 3'UTR dependent processes. Biochem J 473: 4027-4044, 2016.

18. Lee S, Axelsen TV, Andersen AP, Vahl P, Pedersen SF and Boedtkjer E: Disrupting $\mathrm{Na}^{+}, \mathrm{HCO}_{3}^{-}$-cotransporter $\mathrm{NBCn} 1$ (Slc4a7) delays murine breast cancer development. Oncogene 35: 2112-2122, 2016.

19. Lee S, Axelsen TV, Jessen N, Pedersen SF, Vahl P and Boedtkjer E: $\mathrm{Na}^{+}, \mathrm{HCO}_{3}^{-}$-cotransporter NBCn1 (Slc4a7) accelerates ErbB2-induced breast cancer development and tumor growth in mice. Oncogene 37: 5569-5584, 2018.

20. Parks SK and Pouyssegur J: The $\mathrm{Na}(+) / \mathrm{HCO} 3(-)$ co-transporter SLC4A4 plays a role in growth and migration of colon and breast cancer cells. J Cell Physiol 230: 1954-1963, 2015.

21. McIntyre A, Hulikova A, Ledaki I, Snell C, Singleton D, Steers G, Seden P, Jones D, Bridges E, Wigfield S, et al: Disrupting hypoxia-induced bicarbonate transport acidifies tumor cells and suppresses tumor growth. Cancer Res 76: 3744-3755, 2016.

22. Wong P, Kleemann HW and Tannock IF: Cytostatic potential of novel agents that inhibit the regulation of intracellular $\mathrm{pH}$. Br J Cancer 87: 238-245, 2002.

23. Fliegel L: Role of $\mathrm{pH}$ regulatory proteins and dysregulation of $\mathrm{ph}$ in prostate cancer. In: Reviews of Physiology, Biochemistry and Pharmacology Springer Berlin Heidelberg, Berlin, Heidelberg, pp1-26, 2020 . 
24. Korenchan DE, Bok R, Sriram R, Liu K, Santos RD, Qin H, Lobach I, Korn N, Wilson DM, Kurhanewicz J and Flavell RR: Hyperpolarized in vivo $\mathrm{pH}$ imaging reveals grade-dependent acidification in prostate cancer Oncotarget 10: 6096-6110, 2019.

25. Dykes SS, Gao C, Songock WK, Bigelow RL, Woude GV, Bodily JM and Cardelli JA: Zinc finger E-box binding homeobox-1 (Zeb1) drives anterograde lysosome trafficking and tumor cell invasion via upregulation of $\mathrm{Na}+\mathrm{H}+$ Exchanger-1 (NHE1). Mol Carcinog 56: 722-734, 2017.

26. Michel V, Licon-Munoz Y, Trujillo K, Bisoffi M and Parra KJ Inhibitors of vacuolar ATPase proton pumps inhibit human prostate cancer cell invasion and prostate-specific antigen expression and secretion. Int J Cancer 132: E1-E10, 2013.

27. Yu W, Wang L, Wang Y, Xu X, Zou P, Gong M, Zheng J, You J, Wang H, Mei F and Pei F: A novel tumor metastasis suppressor gene LASS2/TMSG1 interacts with vacuolar ATPase through its homeodomain. J Cell Biochem 114: 570-583, 2013.

28. Pertega-Gomes $\mathrm{N}$ and Baltazar F: Lactate transporters in the context of prostate cancer metabolism: What do we know? Int J Mol Sci 15: 18333-18348, 2014.

29. Ibrahim-Hashim A, Cornnell HH, Abrahams D, Lloyd M, Bui M, Gillies RJ and Gatenby RA: Systemic buffers inhibit carcinogenesis in TRAMP mice. J Urol 188: 624-631, 2012.

30. Sun X, Fu X, Li J, Xing C, Frierson HF, Wu H, Ding X, Ju T, Cummings RD and Dong JT: Deletion of atbf $1 / \mathrm{zfh} \times 3$ in mouse prostate causes neoplastic lesions, likely by attenuation of membrane and secretory proteins and multiple signaling pathways. Neoplasia 16: 377-389, 2014.

31. Liang C, Niu L, Xiao Z, Zheng C, Shen Y, Shi Y and Han X: Whole-genome sequencing of prostate cancer reveals novel mutation-driven processes and molecular subgroups. Life Sci 254: 117218, 2020.

32. Lee S, Li JM and Choi I: Sodium bicarbonate cotransporter $\mathrm{NBCe} 1$ affects the growth and motility of prostate cancer cell lines LNCaP and PC3. FASEB J 32: IB411, 2018.

33. Sung H, Ferlay J, Siegel RL, Laversanne M, Soerjomataram I Jemal A and Bray F: Global cancer statistics 2020: GLOBOCAN estimates of incidence and mortality worldwide for 36 cancers in 185 countries. CA Cancer J Clin: Feb 4, 2021 (Epub ahead of print).

34. Strober W: Trypan blue exclusion test of cell viability Curr Protoc Immunol 111: A3.B.1-A3.B.3, 2015.

35. Thomas JA, Buchsbaum RN, Zimniak A and Racker E: Intracellular $\mathrm{pH}$ measurements in Ehrlich ascites tumor cells utilizing spectroscopic probes generated in situ. Biochemistry 18 2210-2218, 1979

36. Livak KJ and Schmittgen TD: Analysis of relative gene expression data using real-time quantitative PCR and the 2(-Delta Delta $\mathrm{C}(\mathrm{T}))$ method. Methods 25: 402-408, 2001.

37. Cooper DS, Yang HS, He P, Kim E, Rajbhandari I, Yun CC and Choi I: Sodium/bicarbonate cotransporter NBCn1/slc4a7 increases cytotoxicity in magnesium depletion in primary cultures of hippocampal neurons. Eur J Neurosci 29: 437-446, 2009.

38. Park HJ, Gonzalez-Islas CE, Kang Y, Li JM and Choi I: Deletion of the $\mathrm{Na} / \mathrm{HCO}_{3}$ transporter NBCn1 protects hippocampal neurons from NMDA-induced seizures and neurotoxicity in mice. Sci Rep 9: 15981, 2019.

39. Zhang B, Ci X, Tao R, Ni JJ, Xuan X, King JL, Xia S Li Y, Frierson HF, Lee DK, et al: Klf5 acetylation regulates luminal differentiation of basal progenitors in prostate development and regeneration. Nat Commun 11: 997, 2020.

40. Ch'en FF, Villafuerte FC, Swietach P, Cobden PM and Vaughan-Jones RD: S0859, an N-cyanosulphonamide inhibitor of sodium-bicarbonate cotransport in the heart. Br J Pharmacol 153: 972-982, 2008

41. Marchiani S, Tamburrino L, Nesi G, Paglierani M, Gelmini S, Orlando C, Maggi M, Forti G and Baldi E: Androgen-responsive and -unresponsive prostate cancer cell lines respond differently to stimuli inducing neuroendocrine differentiation. Int J Androl 33 784-793, 2010

42. Tai S, Sun Y, Squires JM, Zhang H, Oh WK, Liang CZ and Huang J: PC3 is a cell line characteristic of prostatic small cell carcinoma. Prostate 71: 1668-1679, 2011.
43. Majmundar AJ, Wong WJ and Simon MC: Hypoxia-inducible factors and the response to hypoxic stress. Mol Cell 40: 294-309, 2010.

44. Khakipoor S, Ophoven C, Schrödl-Häußel M, Feuerstein M, Heimrich B, Deitmer JW and Roussa E: TGF- $\beta$ signaling directly regulates transcription and functional expression of the electrogenic sodium bicarbonate cotransporter 1, NBCe1 (SLC4A4), via Smad4 in mouse astrocytes. Glia 65: 1361-1375, 2017.

45. Kubiczkova L, Sedlarikova L, Hajek R and Sevcikova S: TGF- $\beta$ - an excellent servant but a bad master. J Transl Med 10 183,2012

46. Namkoong E, Shin YH, Bae JS, Choi S, Kim M, Kim N, Hwang SM and Park K: Role of sodium bicarbonate cotransporters in intracellular $\mathrm{pH}$ regulation and their regulatory mechanisms in human submandibular glands. PLoS One 10 e0138368, 2015.

47. Shirakabe K, Priori G, Yamada H, Ando H, Horita S, Fujita T, Fujimoto I, Mizutani A, Seki G and Mikoshiba K: IRBIT, an inositol 1,4,5-trisphosphate receptor-binding protein, specifically binds to and activates pancreas-type $\mathrm{Na}+\mathrm{HCO}^{-}$cotransporter 1 (pNBC1). Proc Natl Acad Sci USA 103: 9542-9547, 2006.

48. Lee SK, Boron WF and Parker MD: Relief of autoinhibition of the electrogenic $\mathrm{Na}-\mathrm{HCO}(3)$ [corrected] cotransporter NBCe1-B: Role of IRBIT vs. amino-terminal truncation. Am J Physiol Cell Physiol 302: C518-C526, 2012.

49. Bonneau B, Ando H, Kawaai K, Hirose M, Takahashi-Iwanaga $\mathrm{H}$ and Mikoshiba K: IRBIT controls apoptosis by interacting with the Bcl-2 homolog, Bcl2110, and by promoting ER-mitochondria contact. Elife 5: e19896, 2016.

50. Andersen AP, Flinck M, Oernbo EK, Pedersen NB, Viuff BM and Pedersen SF: Roles of acid-extruding ion transporters in regulation of breast cancer cell growth in a 3-dimensional microenvironment. Mol Cancer 15: 45, 2016.

51. Heidtmann H, Ruminot I, Becker HM and Deitmer JW: Inhibition of monocarboxylate transporter by N-cyanosulphonamide S0859. Eur J Pharmacol 762: 344-349, 2015.

52. Majumdar D and Bevensee MO: Na-coupled bicarbonate transporters of the solute carrier 4 family in the nervous system: Function, localization, and relevance to neurologic function. Neuroscience 171: 951-972, 2010.

53. Sanità $\mathrm{P}$, Capulli M, Teti A, Galatioto GP, Vicentini C, Chiarugi P, Bologna M and Angelucci A: Tumor-stroma metabolic relationship based on lactate shuttle can sustain prostate cancer progression. BMC Cancer 14: 154, 2014.

54. Zhong H, Semenza GL, Simons JW and De Marzo AM Up-regulation of hypoxia-inducible factor 1alpha is an early event in prostate carcinogenesis. Cancer Detect Prev 28: 88-93, 2004.

55. Chatterjee S, Schmidt S, Pouli S, Honisch S, Alkahtani S, Stournaras $C$ and Lang F: Membrane androgen receptor sensitive $\mathrm{Na}+\mathrm{H}+$ exchanger activity in prostate cancer cells. FEBS Lett 588: 1571-1579, 2014

56. Ambrosio MR, Di Serio C, Danza G, Rocca BJ, Ginori A, Prudovsky I, Marchionni N, Del Vecchio MT and Tarantini F: Carbonic anhydrase IX is a marker of hypoxia and correlates with higher Gleason scores and ISUP grading in prostate cancer. Diagn Pathol 11: 45, 2016.

57. Svastova E, Witarski W, Csaderova L, Kosik I, Skvarkova L, Hulikova A, Zatovicova M, Barathova M, Kopacek J, Pastorek J and Pastorekova S: Carbonic anhydrase IX interacts with bicarbonate transporters in lamellipodia and increases cell migration via its catalytic domain. J Biol Chem 287: 3392-3402, 2012.

58. Schwab A, Fabian A, Hanley PJ and Stock C: Role of ion channels and transporters in cell migration. Physiol Rev 92: 1865-1913, 2012.

59. O'Connor LJ, Cazares-Körner C, Saha J, Evans CN, Stratford MR, Hammond EM and Conway SJ: Design, synthesis and evaluation of molecularly targeted hypoxia-activated prodrugs. Nat Protoc 11: 781-794, 2016.

60. Frassetto L and Sebastian A: Age and systemic acid-base equilibrium: Analysis of published data. J Gerontol A Biol Sci Med Sci 51: B91-B99, 1996.

This work is licensed under a Creative Commons Attribution-NonCommercial-NoDerivatives 4.0 International (CC BY-NC-ND 4.0) License. 